\title{
DIFFERENCES IN THE MOTOR ABILITIES OF FOOTBALL PLAYERS IN RELATION TO THEIR POSITION ON THETEAM
}

\author{
Živković Mladen, JovanovićVladan, Herodek Katarina, Milanović \\ Zoran, Antić Vladimir \\ Faculty of Sport and Physical Education, University of Nis, Serbia
}

\begin{abstract}
Summary
The aim of this study was to determine if there are differences in the motor abilities of players relative to their position on the team. A total of 27 participants of the football club "Car Konstantin" from Nis, male, age $17 \pm 6$ months participated in this study. The players were divided into three different groups according to their positions: defense ( $n=9)$, midfield $(n=9)$ and attack $(n=9)$. The study examined the differences in the explosive strength of the lower extremities, speed and endurance between the players in relation to their position on the team. In order to carry out the research, the following tests were used: for strength -the countermovement jump, $30 \mathrm{~m}$ sprint speed and for endurance-the shuttle run test. The obtained results were processed by the T-test for independent samples. After the overall analysis it was shown that there were no statistically significant differences in the motor abilities of the players in relation to their position on the team. The main contribution of this paper is to point to the necessity of monitoring the motor skills of players to be able to respond to the demands of modern football. Future research, which deal with the same topics, can based on this study compare the results obtained on the same tests, or focus on other motor skills.
\end{abstract}

Key words: explosive strength, speed, endurance

\section{Introduction}

There are over 240 million people actively involved in football in more than 200 countries worldwide (Hillis, 1998). It is a collective sports game which is characterized by poly-structural movement. Contemporary football requires excellent technique from the players, mutual cooperation, a high level of motor abilities, pronounced cognitive and conative characteristics, all with the aim of achieving the best possible result (Špirtović et al., 2012). Well-developed motor skills are a precondition for the quality performance of technical-tactical elements (Joksimović, 2008). The motor skills which mostly affect the speed of the game of football and limit the movement ability of football players are explosive strength, speed and endurance (Pivovarniček et al., 2013). Explosive strength in football has a direct influence on the performance of quick movement, since it represents the ability of shortterm mobilization of muscle tissue for the increased speed of body movement (Joksimović, 2008). The speed of the football players represents a complex ability which consists of various components that influence the success of the game, and some of them include: short and quick movements, quick move- ments in all directions, the ability to make a quick start and stop, reaction speed, speed of activity with a ball (Gardašević, Bjelica, 2014). Football requires that the players manifest a high level of functional abilities, technical-tactical effectiveness, or in other words morpho-functional universals, in order to act successfully in various situations of the game, often with a lack of time, in limited space and with active intrusions on the part of the opponents. Only a good level of endurance enables the football players to have such a physical state (Stojanović et al., 2015).

\section{Aim and Objectives of the study}

The aim of this study was to determine if there are differences in the motor abilities of the players relative to their position on the team. The main contribution of this study is that it indicates the necessity of monitoring the motor skills of soccer players so that they could meet the demands of contemporary football. Future research, which deal with the same topics, can based on this study compare the results obtained on the same tests, or focus on other motor skills.

\section{Methods}

The sample of participants in this study consisted of 
football players involved in the training process. A total of 27 male players aged $17 \pm 6$ months took part in this study and were divided into three groups. The first group $(n=9)$ consisted of defense players, with an average body height of $177,44 \mathrm{~cm}$, and average body mass $69,11 \mathrm{~kg}$. The second group $(n=9)$ consisted of midfield position players, with an average body height of $178,22 \mathrm{~cm}$, and average body mass of $66,55 \mathrm{~kg}$. The third group $(n=9)$ consisted of attack players, with an average body height of $176,22 \mathrm{~cm}$, and average body mass of $64,77 \mathrm{~kg}$. The anthropometric characteristics of the players were measured in the following manner: body height was measured to a precision of 0,1 $\mathrm{cm}$ (with an anthropometer, according to Martin) and body mass with a precision of $0,1 \mathrm{~kg}$ (Tanita BWB800, Japan). The participants voluntarily agreed to participate in the study which was conducted in accordance with the Helsinki Declaration.

Measuring of the motor skills included the testing of explosive strength of the lower extremities, running speed and endurance.

To evaluate the explosive strength of the lower extremities, the countermovement jump (CMJ) test was used. This test was often used in similar studies so as to evaluate the explosive strength of the lower extremities of football players (Gil, Gil, Ruiz, Irazusta, \&Irazusta, 2007; Lago-Peñas, Casais, Dellal, Rey, \& Domínguez, 2011).Equipment for the evaluation of explosive strength of the lower extremities which was used in this study was the Myotest (Myotest SA, Sion, Switzerland), which provides the technology and methodology for the evaluation of explosive strength. The validity and reliability of the Myotest for the evaluation of jump height was confirmed in the study carried out by Casartelli, Müller, \& $\& a f f$ uletti (2010). Of the four obtained values, which the device indicates, only the variable of jump height $(\mathrm{cm})$ was included in further study.

To evaluate speed, the $30 \mathrm{~m}$ sprint speed test was used. This test is often used in studies to evalu- ate the speed of football players (Pyne, Saunders, Montgomery, Hewitt \& Sheehan, 2008; Spencer, Pyne, Santisteban \& Mujika, 2011; Taşkin, 2008; Kaplan, Erkmen, \& Taskin, 2009). The necessary equipment which was used in this study included photo cells (Witty, Microgate, Bolzano, Italy) which were positioned on the starting line and at the $30 \mathrm{~m}$ mark. The validity and reliability of the photo cells for the evaluation of speed among football players was confirmed in the study of Waldron, Worsfold, Twist, \& Lamb (2011). The result of the test is the time (s) which is needed to cover the set distance.

To evaluate the endurance of football players, the shuttle run test (SRT) was used. This test is often used in similar studies to evaluate the endurance of football players (Lemmink, Verheijen \&Visscher, 2004; Pyne, Saunders, Montgomery, Hewitt \& Sheehan, 2008). The equipment used to perform this test consisted of a computer which emitted a sound signal. The validity and reliability of the shuttle run test was confirmed in the study of Léger \& Lambert (1982). The result of the shuttle run is the achieved level of intensity and the number of covered sections on the achieved level. In order to obtain the value of maximum oxygen uptake(ml.kg- 1 . min-1), the following formula was use:

$\operatorname{VO} 2 \mathrm{Max}=3.46^{*}\left(\mathrm{~L}+\mathrm{SN} /\left(\mathrm{L}^{*} 0.4325+7.0048\right)\right)+12.2$

The statistical analyses included descriptive statistics, the Kolmogorov-Smirnoff test to evaluate the normality of distribution, and to the study of the results between the groups of participants, the T-test for independent samples was used. The statistical significance was set at the $\mathrm{p} \otimes 0,05$ level. All of the data were processed using the statistical package SPSS22.0 (SPSS, Chicago, IL).

\section{Results}

The descriptive statistical indicators and results of the Kolmogorov-Smirnoff test (K-S) of the variables of explosive strength, speed and endurance on the CMJ test, the $30 \mathrm{~m}$ sprint speed test and SRT for participants in all three groups are shown in table 1 .

Table1. Descriptive statistics and the K-Stest

\begin{tabular}{|l|c|c|c|c|c|c|c|c|c|}
\hline \multirow{2}{*}{ Variable (unit) } & \multicolumn{3}{|c|}{ First group } & \multicolumn{3}{c|}{ Second group } & \multicolumn{3}{c|}{ Third group } \\
\cline { 2 - 10 } & Mean & SD & p & Mean & SD & p & Mean & SD & p \\
\hline CMJ $(\mathbf{c m})$ & 39.78 & 3.54 & 0.20 & 35.87 & 3.48 & 0.20 & 37.13 & 3.29 & 0.20 \\
\hline $\mathbf{3 0 m}(\mathbf{s})$ & 4.47 & 0.17 & 0.20 & 4.54 & 0.17 & 0.20 & 4.57 & 0.18 & 0.20 \\
\hline SRT $(\mathbf{m l} / \mathbf{k g} / \mathbf{m i n})$ & 49.10 & 5.28 & 0.20 & 50.93 & 7.72 & 0.15 & 51.24 & 2.39 & 0.06 \\
\hline
\end{tabular}

Legend: Mean-arithmetic means; SD - standard deviation; $\mathbf{p}$ - statistical significance of the Kolmogorov-Smirnoff test

Table 1. shows that the results of the descriptive statistics in relation to the players' positions on the team, 
including arithmetic means and standard deviation. Based on the displayed data and the significance of the normal distribution of the K-S it can be concluded that the distribution of values for all the tested variables is normal. As a result, it is justifiable to use a parametric analysis.

Tables 2., 3. and 4. show the results of the T-test for independent samples which were used to study the differences in the values of explosive strength and endurance between the participants of all three groups. The results shown in the tables were presented in the form of a comparison of the differences between the groups on one test. In table 2. we listed the results of explosive strength obtained on the CMJ test. Table 3. lists the results for speed obtained on the 30 msprint speed test. Table 4 . lists the results of endurance obtained on the SRT test.

Table2. The results of the T-test for independent samples for the values of the CMJ

\begin{tabular}{|c|c|c|c|c|c|}
\hline Variable (unit) & Group & N & Mean & Std. Dev. & Sig. \\
\hline \multirow{2}{*}{ CMJ $(c m)$} & First & 9 & 39.78 & 3.54 & \multirow{2}{*}{0.59} \\
\cline { 2 - 5 } & Second & 9 & 35.87 & 3.48 & \multirow{2}{*}{0.84} \\
\cline { 2 - 5 } CMJ $(c m)$ & First & 9 & 39.78 & 3.54 & \multirow{2}{*}{0.45} \\
\cline { 2 - 5 } & Third & 9 & 37.13 & 3.29 & \\
\cline { 2 - 5 } & Second & 9 & 37.87 & 3.29 & \\
\hline
\end{tabular}

Legend: $\mathbf{N}$ - number of participants, Mean - arithmetic means, Std. Dev. - standard deviation, Sig. - statistical significance

Table3. The results of the T-test for independent samples for the 30msprint speed

\begin{tabular}{|c|c|c|c|c|c|}
\hline Variable (unit) & Group & $\mathbf{N}$ & Mean & Std. Dev. & Sig \\
\hline \multirow{2}{*}{$30 \mathrm{~m}(s)$} & First & 9 & 4.47 & 0.17 & \multirow{2}{*}{0.61} \\
\hline & Second & 9 & 4.54 & 0.17 & \\
\hline \multirow{2}{*}{$30 \mathrm{~m}(s)$} & First & 9 & 4.47 & 0.17 & \multirow{2}{*}{0.36} \\
\hline & Third & 9 & 4.57 & 0.18 & \\
\hline \multirow{2}{*}{$30 \mathrm{~m}(s)$} & Second & 9 & 4.54 & 0.17 & \multirow{2}{*}{0.35} \\
\hline & Third & 9 & 4.57 & 0.18 & \\
\hline
\end{tabular}

Legend: N - number of participants, Mean - arithmetic means, Std. Dev.- standard deviation, Sig.- statistical significance

Table4. The results of the T-test for independent sample for the values of the SRT

\begin{tabular}{|c|c|c|c|c|c|}
\hline Variable (unit) & Group & N & Mean & Std. Dev. & \multirow{2}{*}{ Sig } \\
\hline \multirow{2}{*}{ SRT $(\boldsymbol{m l} / \mathbf{k g} / \mathbf{m i n})$} & First & 9 & 49.10 & 5.28 & \multirow{2}{*}{0.10} \\
\cline { 2 - 5 } & Second & 9 & 50.93 & 7.72 & \multirow{2}{*}{0.60} \\
\hline \multirow{2}{*}{ SRT $(\mathbf{m l} / \mathbf{k g} / \mathbf{m i n})$} & First & 9 & 49.10 & 5.28 & \multirow{2}{*}{0.90} \\
\cline { 2 - 5 } & Third & 9 & 51.24 & 2.39 & 7.72 \\
\hline \multirow{2}{*}{ SRT $(\mathbf{m l} / \mathbf{k g} / \mathbf{m i n})$} & Second & 9 & 50.93 & 2.39 & \\
\cline { 2 - 5 } & Third & 9 & 51.24 & & \\
\hline
\end{tabular}

Legend: $\mathbf{N}$ - number of participants, Mean - arithmetic means, Std. Dev.- standard deviation, Sig.- statistical significance

Based on the obtained results, by comparing the results of all three groups for each test individually, we can conclude that there are no statistically significant differences for the obtained values. The position on the team does not have a statistically significant impact on the differences in the studied motor skills of the football players.

\section{Discussion}

Many studies had the aim to evaluate explosive strength, speed and endurance depending on the players' positions on the team. This kind of study was carried out by Pivovarniček et al. (2013) and involved the football players of the Slovakian national team of players under 21 . They reached the conclusion that there were no significant dif- 
ferences in the studied parameters between the groups divided based on the players' positions on the team. In their study, Nilsson, Cardinale (2015) tested football players of the Swedish league, but the CMJ did not indicate a significant difference between the defensive players, midfield players and attackers, and the same results were reached on the endurance tests. The studies carried out by James (2007) and Swapan, Nabanita, Parthasarthi (2010) also confirm that there are no statistically significant differences in jump height compared to the players' positions on the team. Coelho et al. (2007) compared the success of football players of various positions on the $30 \mathrm{~m}$ sprint speed test and reached the conclusion that the position on the team does not affect this ability. That were no statistically significant difference between the players of various positions in terms of speed was also determined by the authors Milanović et al. (2011), who carried out their research on players from the national team of Serbia of players under the age of 16 .

The cited studies undoubtedly indicate that positions on the team do not influence the development of explosive strength, speed and endurance. The research results from this study support these claims since it was proven that there were no statistically significant differences between defense players, midfield players and attackers for the CMJ, $30 \mathrm{~m}$ sprint sped and SRT tests used to evaluate precisely these motor areas.

\section{Acknowledgements}

We gratefully acknowledge the Ministry of Education, Science and Technological Development of the Republic of Serbia support and financing of the current research within the project № 179024 .

\section{References}

Casartelli, N., Müller, R., and Maffiuletti, N. A. (2010). Validity and reliability of the Myotest accelerometric system for the assessment of vertical jump height. The Journal of Strength \& Conditioning Research, vol. 24, no. 11, pp. 3186-3193.

Coelho, B. D., Braga, M. L. P., Campos, P. A. F., Condessa, L. A., Mortimer, L.C. F., Danusa, D. S., Paolucci, A., and Garcia, E. S. (2007). Performance of soccer players of different playing positions and nacionalities in a 30 - meter sprint test, In: Menzel, H., and Chagas, M., H. (Eds), 25 Internacional Symposium on Biomechanics in sport in Ouro Preto,
Brazil, August, 23-27, 2007, pp. 362-365.

Gardašević, J., and Bjelica, D. (2014). Efekti rada u pripremnom periodu na brzinu vođenja lopte petnaestogodišnjih fudbalera (The effects of the training in the preparation period on the dribbling speed with fifteen years old football players). Sport mont, vol. 40-42, pp. 160-166.

Gil, S. M., Gil, J., Ruiz, F., Irazusta, A., and Irazusta, J. (2007), Physiological and antropometric characteristics of young soccer players according to their playing position: relevance for the selection process. The Journal of Strenght \& Conditioning Research, vol. 21, no. 2, pp. 438-445.

Hillis, S. (1998). Preparations for the World cup. British Journal of Sports Medicine, vol. 32, pp. 95.

James, R. K. (2007). Positional assessment and physical fitness characteristics of male professional soccer players in South Africa. African journal for physical, health education, recreation and dance, vol. 13, no. 4, pp. 453-464.

Joksimović, A. (2008). Mali fudbal (Futsal). Niš: GIP „TIMOK“ D.O.O.

Kaplan, T., Erkmen, N., and Taskin, H. (2009). The evaluation of the running speed and agility performance in professional and amateur soccer players. Journal of Strenght \& Conditioning Research, vol. 23, no. 3, pp. 774-778.

Lago - Peñas, C., Casais, L., Dellal, A., Rey, E., and Domínguez, E. (2011). Anthropometric and physiological characteristics of young soccer players according to their playing positions: relevance for competition success. The Journal of Strength \& Conditioning Research, vol. 25, no. 12, pp. 3358-3367.

Léger, L. A., and Lambert, J. (1982). A maximal multistage $20 \mathrm{~m}$ shuttle run test to predict $V O_{2 \max }$. European Journal of Applied Physiology, vol. 49, pp. $1-5$.

Lemmink, K. A. P. M., Verheijen, R. \& Visscher, C. (2004). The discriminative power of the interval shuttle run test an the maximal multistage shuttle run test for playing level of soccer. Journal of Sports Medicine and Physical Fitness, vol. 44, no. 3, pp. 233-239. 
Milanović, Z., Daly, D., Trajković, N., and Sporiš, G. (2011). Razlike u brzini, ubrzanju i agilnosti kod mladih fudbalera u odnosu na poziciju u timu (Differences in speed, acceleration and agility of young footballers in relation to the position in team). In: Živanović., N. (Ed.), XV међународни научни скуп Фис комуникације у спорту физичком васпитању и рекреацији (XV International Congress Fis Communications'9 in Sport, Physical Education, and Recreation) in Nis, Serbia, October, 20-22,2011, Niš, pp. 261-266.

Nilsson, J., and Cardinale, D. (2015). Aerobic and anaerobic test performance among elite male football players in different team positions. Lase Journal of Sport Science, vol.6, no. 2, pp. 73-92.

Pivovarniček, P., Pupiš, M., Tonhauserova, Z., and Tokárová, M. (2013). Nivo sprinterskih sposobnosti, eksplozivne snage i specijalne izdržljivosti vrhunskih mladih fudbalera na različitim pozicijama (Level of sprint and jump abilities and intermittent endurance of elite young soccer players at different positions). Sport Logia, vol. 9, no. 2, pp. 186-200.

Pyne, D. B., Saunders, P. U., Montgomery, P. G., Hewitt, A. J., and Sheehan, K. (2008). Relationships between repeated sprint testing, speed, and endurance. Journal of Strenght \& Conditioning Research, vol. 22, no. 5, pp. 1633-1637.

Spencer, M., Pyne, D., Santisteban, J., and Mujika, I. (2011). Fitness determinants of repeated-sprint ability in highly trained youth football players. International Journal of Sports Physiology and Performance, vol. 6, pp. 497-508.

Stojanović, T., Goranović, S., Šakanović, A., and Stojanović, D. (2015). Nivo specifične izdržljivosti i tehničko - taktičke efikasnosti mladih fudbalera različitog stepena takmičenja (The level of specific endurance and technical and tactical efficiency of young football players of different level of competition). Sports science and health, vol. 5, no. 2, pp. 141-150.

Swapan, K. D., Nabanita, K., and Parthasarthi, D. (2010). Antropometric, motor ability and physiological profiles of indian national club footballers: A comparative study. South African journal for research in sport, physical education and recreation, vol. 32, no. 1, pp. 43-56.

Špirtović, O., Aćimović, D., and Joksimović, A. (2012). Razlike u nivou situaciono - motoričkih sposobnosti fudbalera različitog ranga takmičenja (Differences in the level of situational -motor abilities of football players of different level competitions). Sport mont, vol. 34-36, pp. 391-394.

Taşkin, H. (2008). Evaluating sprinting ability, density of acceleration, and speed dribbling ability of professional soccer players with respect to their positions. Journal of Strenght \& Conditioning Research, vol. 22, no. 5, pp. 1481-1486.

Waldron, M., Worsfold, P., Twist, C., and Lamb, K. (2011). Concurrent validy and test-retest reliability of a global positioning sistem (GPS) and timing gates to assess sprint performance variables. Journal of Sport Sciences, vol. 29, no. 15, pp. 1613-1619.

\section{Contact information with the corresponding author:}

\section{Živković Mladen, PhD, Assistant Professor}

Faculty of Sport and Physical Education, University of Niš

Čarnojevića street $10 \mathrm{a}$ $18000 \mathrm{Niš}$

Serbia

Tel: +381631045845

Fax: $+38118242-482$

E-mail: profzile@gmail.com 